\title{
Oral health knowledge of elementary students
}

\author{
Indah Dewi Yvatrani*, Asty Samiaty Setiawan*, Dede Sutardjo* \\ *Department of Public Health Faculty of Dentistry Universitas Padjadjaran
}

\begin{abstract}
Introduction: Dental treatment is considered not very important, but the benefits are vital in supporting health and appearance. Oral health knowledge affects a person's behavior of maintaining oral hygiene. Efforts to oral health care should be done at early age. The purpose of this study was to determine oral health knowledge of students in grade 5 and 6 of Sekeloa 1 and 2 Elementary School Bandung. Methods: This study was a descriptive study with survey method. The method used in sampling was total sampling with a sample size of 158 students in grade 5 and 6 in Sekeloa 1 and 2 Elementary School Bandung. The data was obtained by distributing questionnaires to the objects. Results: Oral health knowledge of student's in grade 5 and 6 in Sekeloa 1 and 2 Elemantary School Bandung are in 38 respondents (24.1\%) with good category; 85 respondents $(53,8 \%)$ with moderate category; and 35 respondents $(22.2 \%)$ with less category. Conclusion: Oral health knowledge of 5 and 6 grades of Sekeloa 1 and 2 Elementary School Bandung was moderate.
\end{abstract}

Keywords: dental and oral health knowledge

\section{INTRODUCTION}

The vision of the Ministry of Health is a healthy, self-reliant and just society, while the Department of Health's mission to achieve that vision is to improve public health, through empowerment, including private and civil society, and protect public health by ensuring a full, and fair. ${ }^{1}$

Bloom explained there are 4 main factors that affect the degree of public health. The four factors consist of behavioral factors / lifestyle, environmental factors (social, economic, political, cultural), health care factors (type of coverage and quality) and genetic factors (heredity). Human behavior factor is the biggest determinant factor and the most difficult to be overcome, followed by environmental factor. ${ }^{2}$
Dental health efforts need to be viewed from environmental aspects, knowledge, education, community awareness and dental health care including prevention and treatment, but most people ignore the condition of dental health as a whole. Dental treatment is considered not very important, but the benefits are vital in supporting health and appearance. ${ }^{3}$ Dental health status of Bandung residents can be assessed among others from the indicator of tooth decay rate (DMF-T index), the population with at least 20 functioning teeth, the number of residents is not toothed. Based on the results of Riskesdas Jabar 2007, DMF-T population of Bandung is 6.29.4

Knowledge of oral and dental health can affect a person's behavior in maintaining oral hygiene. Oral health care efforts should be done 
from an early age. Primary school age is an ideal time to train a child's motor skills, including brushing teeth. The process of oral health education is an educational process that arises on the basis of the need for oral health. ${ }^{5}$ The age of primary school is often referred to as the intellectual period or the period of school compatibility. 6 Objects in this study are elementary school students in grade 5 and grade 6 , lasting between the ages of 10 to 12 years. Ages 10 to 12 , children begin to show manipulative skills resembling adult abilities. ${ }^{7}$

SDN Sekeloa 1 and 2 is one of the public schools in Bandung located in North Sekeloa Street No.30 A. The location of SDN Sekeloa 1 and 2 is located around Dental and Oral Hospital of FKG Unpad which is one of dentistry education institution service provider dental and oral health, as one of the dental education institutions and has an obligation to participate in improving the health status of dental and mouth community.

Preliminary observation that some 5 th and 6th grade students of SDN 1 and 2 Sekeloa have already been treated to Dental and Oral Hospital of FKG Unpad, it can be an evaluation material whether the student ever get direction about oral health knowledge or never get directions about dental and oral health knowledge.

Based on the above background, the aim of this research are determine oral health knowledge of students.

\section{METHODS}

The type of research is descriptive research with survey method, which is a research conducted to describe or describe a phenomenon that occurs in society. ${ }^{8}$

The population of the study is 5th and 6th grade students at SDN Sekeloa1 and 2 Bandung at the time of this research. The population criteria in this research are: Male and female, willing to fill out questionnaires.

The sampling technique used is the total sampling method. Sample determination technique is used where all members of the population are used as samples.

Tools and materials used in the study include: Sheets of questionnaires containing general data and questions about dental and oral health of respondents and stationery. ${ }^{9}$

\section{RESULTS}

The result of research on oral and dental health knowledge of 5th and 6th grade students at SDN Sekeloa 1 and 2 was obtained from questionnaires distributed to 158 respondents. Based on Table 1 , it is found that most of the respondents answered correctly about the question about one dental function as much as 155 people (98.1\%). In addition, it is seen that 5th and 6th grade students in SDN Sekeloa 1 and 2 who answered incorrectly about the process of cavities as much as 147 people $(93 \%)$

Based on the table 2, it shows that the dental and oral health knowledge of 5th and 6th grade students in SDN Sekeloa 1 and 2 Bandung is 38 respondents $(24.1 \%)$ with good category, 85 respondents $(53,8 \%)$ with medium category , and 35 respondents (22.2\%) with less category.

Tabel 1 Frequency Distribution Oral Health Knowledge of Grade 5 and Grade 6 Students at SDN Sekeloa 1 and 2 Bandung

\begin{tabular}{|l|l|c|c|c|c|}
\hline \multirow{2}{*}{ No } & \multirow{2}{*}{ Questions } & \multicolumn{2}{|c|}{ Correct } & \multicolumn{2}{c|}{ Wrong } \\
\cline { 3 - 6 } & & $\mathrm{F}$ & $\%$ & $\mathrm{~F}$ & $\%$ \\
\hline 1 & One tooth function & 155 & 98.1 & 3 & 1.9 \\
\hline 2 & Outer layer of teeth & 68 & 43 & 90 & 57 \\
\hline 3 & Total number of & 35 & 22.2 & 123 & 77.8 \\
\hline 4 & Fermanent teeth & & & & \\
\hline 5 & Fucntion of caninces & 112 & 70.9 & 46 & 29.1 \\
\hline 6 & $\begin{array}{l}\text { Process of cavity } \\
\text { formation }\end{array}$ & 11 & 7 & 147 & 93 \\
\hline 7 & Factor of tooth cavity & 144 & 91.1 & 14 & 8.9 \\
\hline 8 & Definition of plaque & 78 & 49.4 & 80 & 50.6 \\
\hline 9 & Harden plaque & 102 & 64.6 & 56 & 35.4 \\
\hline 10 & Inflammation on gums & 88 & 55.7 & 70 & 44.3 \\
\hline 11 & Colour of the healthy & 102 & 64.6 & 56 & 35.4 \\
\hline 12 & gums & 110 & 69.6 & 48 & 30.4 \\
\hline 13 & Good oral habit & 145 & 91.8 & 13 & 8.2 \\
\hline 14 & $\begin{array}{l}\text { Food and Beverages } \\
\text { that is good for teeth }\end{array}$ & 145 & 91.8 & 13 & 8.2 \\
\hline 15 & Benefit of fluoride & 130 & 82.3 & 28 & 17.7 \\
\hline 16 & Plaque cleaning & 137 & 86.7 & 21 & 13.3 \\
\hline 17 & Tools to clean teeth & 115 & 72.8 & 43 & 27.2 \\
\hline 18 & Period and freuquency \\
& of tooth brushing & 102 & 64.6 & 56 & 35.4 \\
\hline 19 & Action taken after & 151 & 95.6 & 7 & 4.4 \\
\hline & tooth cavity detection & & & & \\
\hline & & & & & \\
\hline
\end{tabular}


Table 2 Level of Dental and Oral Health Knowledge Class 5 and Class 6 in SDN Sekeloa 1 and 2 Bandung

\begin{tabular}{|c|c|c|}
\hline Level of knowledge & $\mathrm{f}$ & $\%$ \\
\hline Good & 38 & 24,1 \\
\hline Fair & 85 & 53,8 \\
\hline Bad & 35 & 22,2 \\
\hline Total & 158 & 100 \\
\hline
\end{tabular}

\section{DISCUSSION}

Based on Table 1, it can be seen that statements about dental and oral health knowledge of dental anatomy are sufficient, where as many as 68 respondents or $43 \%$ answered correctly about the outer layer of the teeth. The outer layer of the tooth is email, email is the hardest tooth layer. Table 1 also shows that children's knowledge about the function of teeth in life is good, as many as 155 respondents or $98.1 \%$ responded correctly.

Based on Table 1, the process of cavities occurs in the low category of all statements given to respondents only $7 \%$ of 158 respondents answered wrong. The process of cavities is important for children in grades 5 and 6 .

This is related to the guidelines made by the Indonesian Dental Health Foundation (2008), 10 that 5th graders and 6th graders should have understood the process of cavities, but this is contrary to the statement about the impact of cavities, as many as 144 people respondents or 91.1\% answered correctly, should if children know about the impact of cavities the child is more concerned to maintain healthy teeth and mouth. ${ }^{10}$

Based on Table 1, of all statements given to the respondents was 78 respondents or $49.4 \%$ knew about plaque understanding. Plaque is the etiology of dental and oral diseases. Plaque is a soft deposit that covers and attaches to the tooth surface consisting of a wide variety of bacteria, this is the factor of the incidence of cavities. ${ }^{11}$ It is important to know by the child, in order to maintain the cleanliness of the mouth so that the accumulation of plaque does not occur.

The plaque that gradually becomes mineralized and hardened, the hardened plaque is called calculus or tartar, according to Table 1, 102 respondents or $64.6 \%$ know about tartar. ${ }^{12}$ Table 1 also shows 102 respondents or $64,6 \%$ know the color of healthy gums. A healthy gum sign is a pink, strong and chewy gum. ${ }^{13}$
Based on Table 1, about 145 respondents or $91.8 \%$ answered correctly about good habit to brush teeth. A good habit in brushing your teeth is to brush your teeth using fluoride toothpaste and a good selection of toothbrushes.

The selection of a good toothbrush for children is to choose soft bristles, determine the preferred color of the child, adjust to the jaw size of the child, if the jaw is small select a toothbrush with short and narrow fur, while for larger jaws select wider feathers and more suitable. ${ }^{14}$

Children already know good food for dental health, this is seen from the statement given to the respondents, as many as 145 people respondents or $91.8 \%$ answered correctly. Good nutrition is very important for physical health, nutrition plays a role in the development and maintenance of a healthy mouth, especially in the teeth and gums.

The food we consume affects dental health. Good dental hygiene begins early in life and should be done throughout life. ${ }^{15}$ Choosing healthy foods may sound easy, but fruits, milk, cereals, bread and some vegetables can be selected. Carbonated soda, sugary drinks and sugary snacks should be limited. ${ }^{16}$

The benefit of fluorine is to reinforce emails, based on Table 1 , as many as 130 respondents or 82, $13 \%$ correctly answer about the benefits of fluorine. Fluorine is a mineral material used by humans as a material that can make enamel layers more resistant to acid, the acid produced by germs in plaque so that the tooth becomes perforated. ${ }^{10}$ Fluoride serves to keep the tooth is not hollow. ${ }^{17}$

Based on Table 1, as many as 137 respondents or $86.7 \%$ know how to clean plaque by brushing teeth. Brushing is a mechanical way to remove dental plaque. The tooth-brushing technique is widely recommended by experts as it is considered to be quite effective in clearing dental plaque, the technique of bass modification. ${ }^{17}$

Bass technique is an appropriate technique performed by individuals with or without periodontal disease. ${ }^{18}$ Table 1 also shows that 102 respondents or $64.6 \%$ know the right time and frequency to brush your teeth. The proper time and frequency to brush your teeth in a day is twice daily after eating and before bed. ${ }^{19}$

A tool for cleaning teeth other than toothbrush is dental floss, 115 respondents or $72.8 \%$ are correct. Based on Table 1, of all statements 
given to the respondents, 151 respondents or 95.6\% answered correctly the statement about going to dentist what if the cavities are cavities.

This is in line with the research conducted by Wiguna (2011) on the knowledge of dental and oral health of 12-year-old students in SMP Negeri 5 Bandung, if cavities, the action should be done immediately checked the dentist and not treated himself.

Table 1 also shows that of all statements given, as many as 69 respondents or $43.7 \%$ responded incorrectly to statements about good dental control time. This is due to the lack of socialization from the school, related agencies about the good time to control dentist.

This is in line with that disclosed by Farida (2009) that to check dental and oral health of dentist at least every two years although not toothache, and maintain healthy teeth and mouth should brush teeth regularly.

Based on the research that has been done, in general, students of grade 5 and grade 6 in SDN Sekeloa 1 and 2 Bandung have enough understanding and know about dental and mouth health, but still need guidance and attention so that knowledge about oral health is increasing.

\section{CONCLUSION}

Oral health knowledge of 5th and 6th grade students at SDN Sekeloa 1 and 2 Bandung, including in medium criterion.

\section{REFERENCES}

1. Depkes RI. Profil Kesehatan Indonesia. 2010.

2. Wimee Kes. Teori Blum H.L. Konsep hidup sehat H.L.Blum. Avaliable from: https:// wimee.wordpress.com/2011/06/20/teori-h-lblum/

3. Kawuryan Uji. Hubungan Pengetahuan Tentang Kesehatan Gigi Dan Mulut Dengan Kejadian Karies Gigi Anak Sdn Kleco II Kelas V Dan VI Kecamatan Laweyan Surakarta. Skripsi UMSUR : Surakarta. 2008.

4. Widyowati W. Pengabdian Masyarakat FKG UNPAD. 2010. Available online at: http:// bataviase.co.id/node/295801 (diakses 8 Desember 2011 10.28 PM).

5. E Riyanti, Saptarini R. Upaya Peningkatan Kesehatan Gigi Dan Mulut Melalui Perubahan Perilaku Anak. 2010.

6. Yusuf S. Psikologi Perkembangan Anak Dan Remaja. Bandung : PT Remaja Rosdakarya. 2007. 24-25; 54; 178-184 pp.

7. Santrock, J.W. Child Development. $14^{\text {th }}$ Ed. New York: McGraw-Hill. 2014

8. Notoatmodjo S. Ilmu Kesehatan Masyarakat -Prinsip-Prinsip Dasar. Jakarta : PT. Rineka Cipta. 2003. 127-128; 146 pp.

9. Sugiyono. Metode Penelitian Kuantitatif, Kualitatif, Dan R\&D. Bandung : Alfabeta. 2011. 85 pp.

10. YKGI. Pendidikan Kesehatan Gigi Untuk Sekolah Dasar. Yayasan Kesehatan Gigi Indonesia: Bandung. 2008. 1; 22 pp. 
